\title{
Effect of drying methods for inner parameters of red beetroot (Beta vulgaris L.)
}

\author{
D. Székely \\ e-mail: babinszky-szekely.dora@etk.szie.hu

$$
\text { M. Stéger-Máté }
$$

e-mail: stegerne.mate.monika@etk.szie.hu

\author{
B. Illés \\ e-mail: gitta0814@gmail.com
}

J. Monspart-Sényi

e-mail: monspart.elemerne@etk.szie.hu

\section{Department of Food Preservation, \\ Faculty of Food Science, \\ Szent István University,}

1118, Villányi út 29-43., Budapest, Hungary

\begin{abstract}
In compliance with consumer expectations, careful processing and preservation are increasingly used with fruits and vegetables. The aim is that during these treatments the valuable nutritional characteristics of the raw materials change as little as possible. Drying has been used for the preservation of raw materials for a long time, which can distinguish two different groups based upon pressure. These are the atmospheric and the more careful vacuum drying.

During the research, Alto F1 beetroots were being dried in vacuum and under atmospheric pressure at different temperatures. Vacuum drying took place at 40,50 , and $60^{\circ} \mathrm{C}$, while atmospheric drying at 60 , 70 , and $80^{\circ} \mathrm{C}$. All drying processes lasted 150 minutes. During drying, changes of moisture content and water activity were monitored. After drying, colour measurement was realized and the inner parameters were investigated, such as polyphenol, betalain, and antioxidant capacity. These measured parameters were compared in the case of atmospheric and vacuum drying.
\end{abstract}

Keywords and phrases: beetroot, atmospheric drying, vacuum drying 


\section{Introduction}

Although the consumption of vegetables is becoming more and more prevalent, the consumption of beetroot in our country is very low despite that numerous researches demonstrate its cancer-preventive, antioxidant, and antiinflammatory effect. In addition, its nutritional content is very favourable; besides the high fibre and mineral content, vitamin $\mathrm{C}$ and folic acid are substantial. Especially in fresh or in bottled form, it is applied to colour yogurts and cookies because of its large amount of pigments (betanin, vulgaxantin I-II). The consumption of dried red beet is becoming more and more common. Beetroot (Beta vulgaris L. ssp. esculenta Gurke var. rubra L.) has already been grown since antiquity. The wild ancestor of beetroot is Beta vulgaris var. maritima, which can be found mainly around the Mediterranean Sea. The Romans, Greeks, and Egyptians were familiar with its wild variety used for direct consumption - this has been known only since the XIX-XX. centuries (Hájas, 1976).

Although healthy lifestyle receives more and more emphasis, so the beneficial effects of the consumption of beetroots is well-known, the consumption per capita is only $0.5 \mathrm{~kg}$ a year. This amount is higher in other European countries. People in Northern Europe, Japan, the UK, and Germany show a preferance for consuming beetroots (Balázs, 2004).

Beetroot has excellent physiological properties. Its macro- and micronutrient content is remarkable and its vitamin content is high. Its vitamin A and $\mathrm{C}$ content is substantial and its vitamin B is outstanding. Vitamin B1 (thiamine), vitamin B2 (riboflavin), and vitamin B3 (niacin) can be found in most root vegetables with dark green leaf, such as in beetroot. Beetroots play a vital role due to their remarkable folate content. Folic acid helps to prevent cancer and in cooperation with vitamin B contributes to the proper functioning of the nervous system (Takácsné, 2002).

Betalain - water-soluble, nitrogen-containing plant pigments - gives the red colour of red beet (Ravichandran et al., 2013). Beetroot has a lot of positive properties for the human body. It has antioxidant, anti-inflammatory, hepatoprotective, and anticancer effects (Nemzer, 2011). The colouring effect of betalain shows similarity with the anthocyanin compounds (Csapó \& Csapóné, 2003). Betalains can be divided into two groups based on their colour: redpurple betacyanin and yellow betaxanthin (Georgiev et al., 2010). 


\section{Materials and methods}

\section{$2.1 \quad$ Materials}

The Alto F1 beet variety was grown in the Experimental Plant of Tan's economy at the Faculty of Horticultural Sciences, Szent István University. During cultivation, beetroots were treated with Genesis fertilizer, which contains the followings: $27 \%$ nitrate, $5 \% \mathrm{MgO}$, and $7 \% \mathrm{CaO}$. Beetroots used in the experiment were harvested in July 2014. After harvesting, they were washed, peeled, and sliced into $2 \mathrm{~mm}$ slices, and then they were stored in frozen state at $18^{\circ} \mathrm{C}$ for 2 weeks.

\subsection{Methods}

Drying lasted 150 minutes. The following drying instruments were used: MEMMERT-VO vacuum drying and LP-322 type drying oven. Based on the experimental plans, drying was done in vacuum at 40,50 , and $60^{\circ} \mathrm{C}$ (sample codes: $40 \mathrm{~V}, 50 \mathrm{~V}, 60 \mathrm{~V}$ ) and in drying oven at 60,70 , and $80^{\circ} \mathrm{C}$ (sample codes 40L, 50L, 60L). After drying, beetroots were extracted. Nutrition characteristics were assessed in the dried and extracted beetroots.

Sampling was done every 30 minutes in each case. Subsequently, moisture content - Kern DBS 60-3 - and water activity - LabMaster-aw - of the samples were determined. The chemical tests (polyphenol content (Singleton \& Rossi, 1965), antioxidant capacity (Benzie \& Strain, 1996), betacyanin (Castellar et al., 2003) and betaxanthin content (Stinzinget et al., 2005), and the physical measurements (rewetting, colour measurement - Minolta CR 200) were carried out only in the case of dried beetroots. During rewetting, the absorption index, or rehydration ratio $(\mathrm{RR})$ is the ratio of rehydrated product weight $(\mathrm{Wr})$ and the dry weight of the product $(\mathrm{Wd})$ of the dried beetroot samples.

\section{Results and discussion}

The aim of my work was to compare the nutritional characteristics of the dried beetroots using vacuum drying and drying oven. During the evaluation of the results, the received values were compared.

Figure 1 shows the changes of the moisture content. During the same drying time, the moisture content of the $60 \mathrm{~V}, 60 \mathrm{~L}, 70 \mathrm{~L}$, and $80 \mathrm{~L}$ samples are almost identical. Vacuum drying at 40 and $50^{\circ} \mathrm{C}$ would require a longer drying period to reach a moisture content under $10 \%$. 


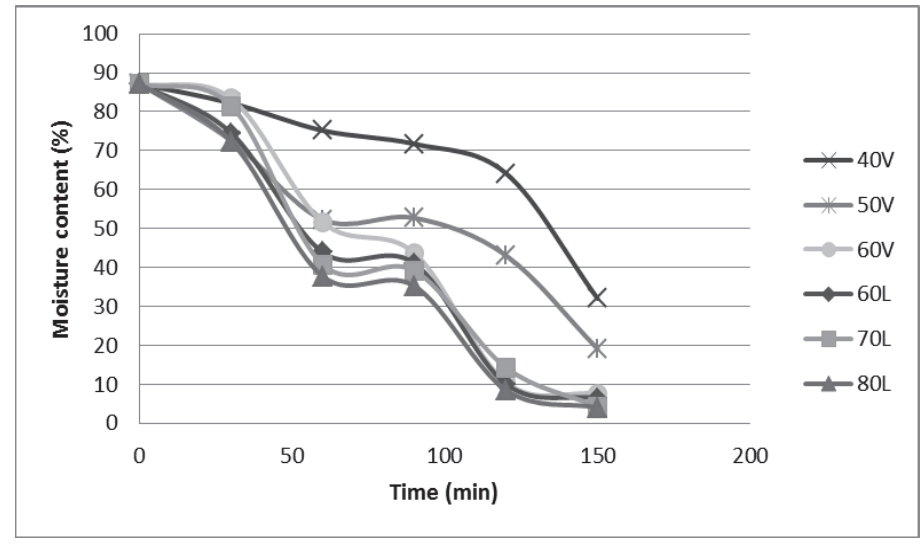

Figure 1: Moisture content in the case of different drying parameters

Table 1 presents the final moisture content after drying.

Table 1: Moisture content and water activity

\begin{tabular}{lcc}
\hline & Moisture content (\%) & Water activity \\
\hline $40 \mathrm{~V}$ & 32.000 & 0.791 \\
$50 \mathrm{~V}$ & 19.100 & 0.567 \\
$60 \mathrm{~V}$ & 7.557 & 0.400 \\
$60 \mathrm{~L}$ & 6.416 & 0.453 \\
$70 \mathrm{~L}$ & 4.262 & 0.405 \\
$80 \mathrm{~L}$ & 4.023 & 0.310 \\
\hline
\end{tabular}

Figure 2 shows the water activity of the samples during drying. Sampling was taken every 30 minutes. The initial water activity of the raw material was the same $\left(\mathrm{a}_{\mathrm{w}}=0.892\right)$ in all cases.

Among the samples, the $40 \mathrm{~V}$ shows the smallest change. In the case of vacuum drying, a substantial reduction of water activity occurred only after 90 minutes of drying, but with the drying oven this set in after 60 minutes of drying.

Figure 3 contains the rewetting rate of the dried samples. It can be observed that the $60 \mathrm{~V}$ shows the highest rewetting rate, which is due to mild drying. In the case of the $50 \mathrm{~V}(\mathrm{RR}=2,8)$ and $40 \mathrm{~V}(\mathrm{RR}=2,272)$, rewetting rate becomes increasingly smaller as in these samples the final moisture contents were $19.1 \%$ and $32 \%$; so, during rewetting, these samples absorbed less water. 


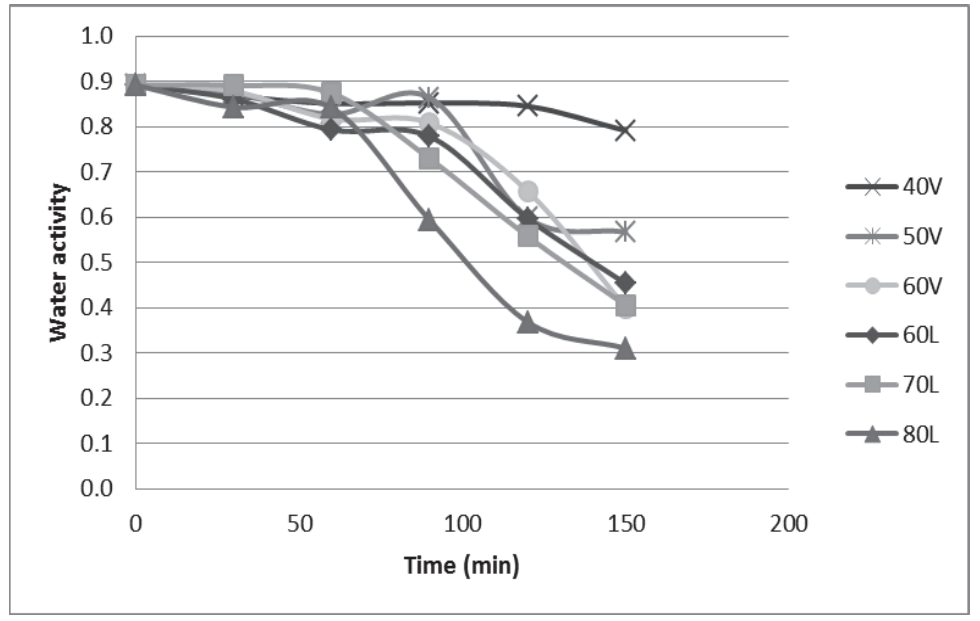

Figure 2: Water activity in the case of different drying parameters

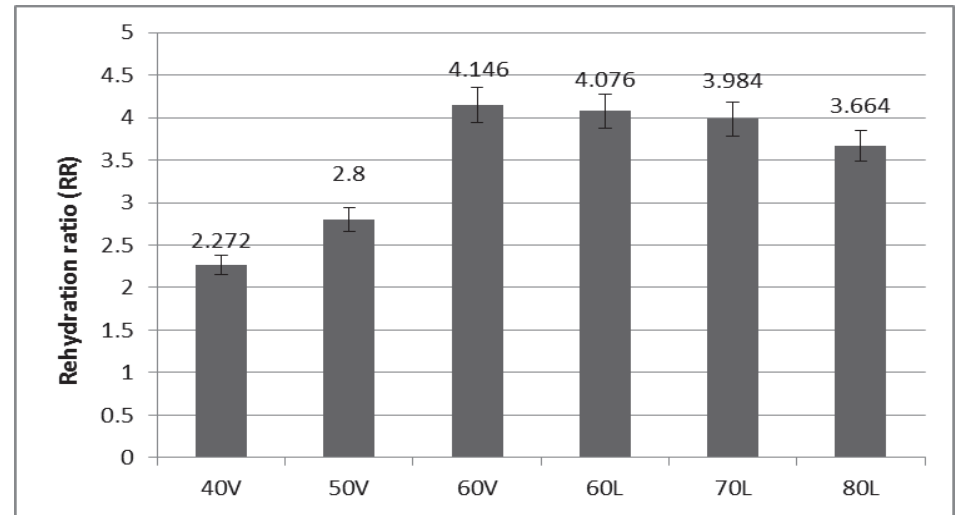

Figure 3: Rehydration ratio of the dried samples

As the drying temperature is raised, the colour difference values $(\Delta \mathrm{E})$ of the consecutive samples are compared to each other in Table 3. Between the 40 $\mathrm{V}$ and $50 \mathrm{~V}, 60 \mathrm{~V}$ and $60 \mathrm{~L}$, and $70 \mathrm{~L}$ and $80 \mathrm{~L}$ samples, the deviation is clearly visible, while the difference between the $50 \mathrm{~V}$ and $60 \mathrm{~V}$ and $60 \mathrm{~L}$ and $70 \mathrm{~L}$ samples is barely noticeable. 
Table 2: Results of the colour measuremnets in the case of dried samples

\begin{tabular}{ccccccc}
\hline Parameters & $40 \mathrm{~V}$ & $50 \mathrm{~V}$ & $60 \mathrm{~V}$ & $60 \mathrm{~L}$ & $70 \mathrm{~L}$ & $80 \mathrm{~L}$ \\
\hline $\mathrm{a}^{*}$ & 7.46 & 5.23 & 4.46 & 1.38 & 1.49 & 1.28 \\
$\mathrm{~b}^{*}$ & 1.87 & 1.46 & 1.23 & 0.61 & 0.60 & 0.54 \\
$\mathrm{~L}^{*}$ & 21.42 & 18.72 & 19.48 & 20.17 & 20.33 & 22.17 \\
\hline
\end{tabular}

Table 3: Values of the colour differences between each sample pair

\begin{tabular}{ccl}
\hline Samples & $\Delta \mathrm{E}$ & Differences perceptible to the eye \\
\hline $40 \mathrm{~V}-50 \mathrm{~V}$ & 3.52 & Clearly visible \\
$50 \mathrm{~V}-60 \mathrm{~V}$ & 1.10 & Barely noticeable \\
$60 \mathrm{~V}-60 \mathrm{~L}$ & 3.22 & Clearly visible \\
$60 \mathrm{~L}-70 \mathrm{~L}$ & 0.19 & No noticeable \\
$70 \mathrm{~L}-80 \mathrm{~L}$ & 1.86 & Noticeable \\
\hline
\end{tabular}

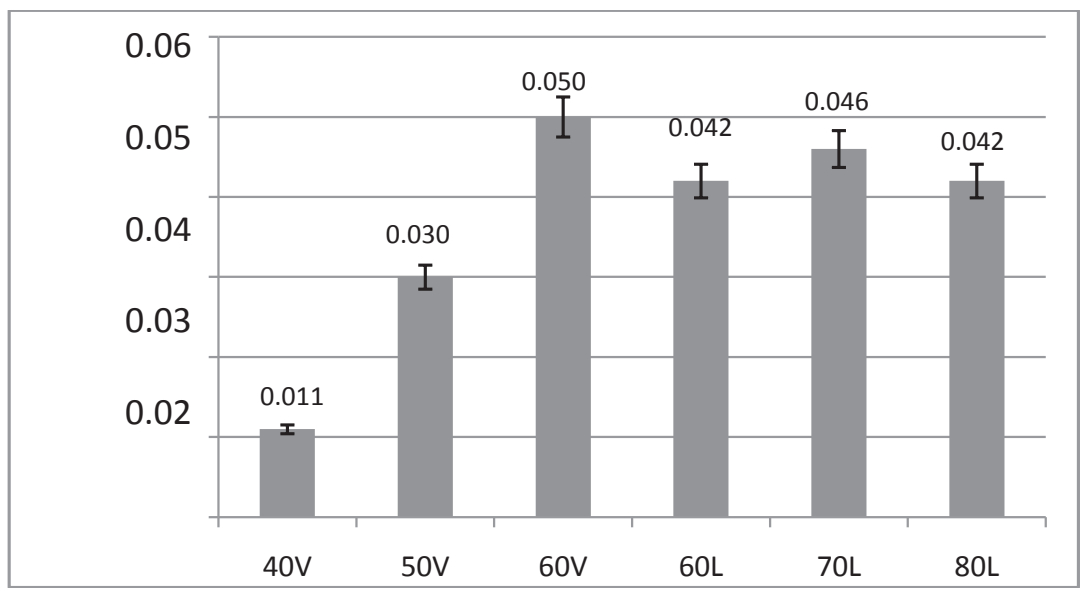

Figure 4: Antioxidant capacity of the dried samples

Figure 4 contains the antioxidant capacity of the dried samples. The highest antioxidant capacity $(0.05 \mathrm{mg} / 100 \mathrm{~g})$ can be seen in the $60 \mathrm{~V}$ sample, but the antioxidant capacity of the $70 \mathrm{~L}$ samples $(0.046 \mathrm{mg} / 100 \mathrm{~g})$ is slightly smaller. 
D. Székely et al.

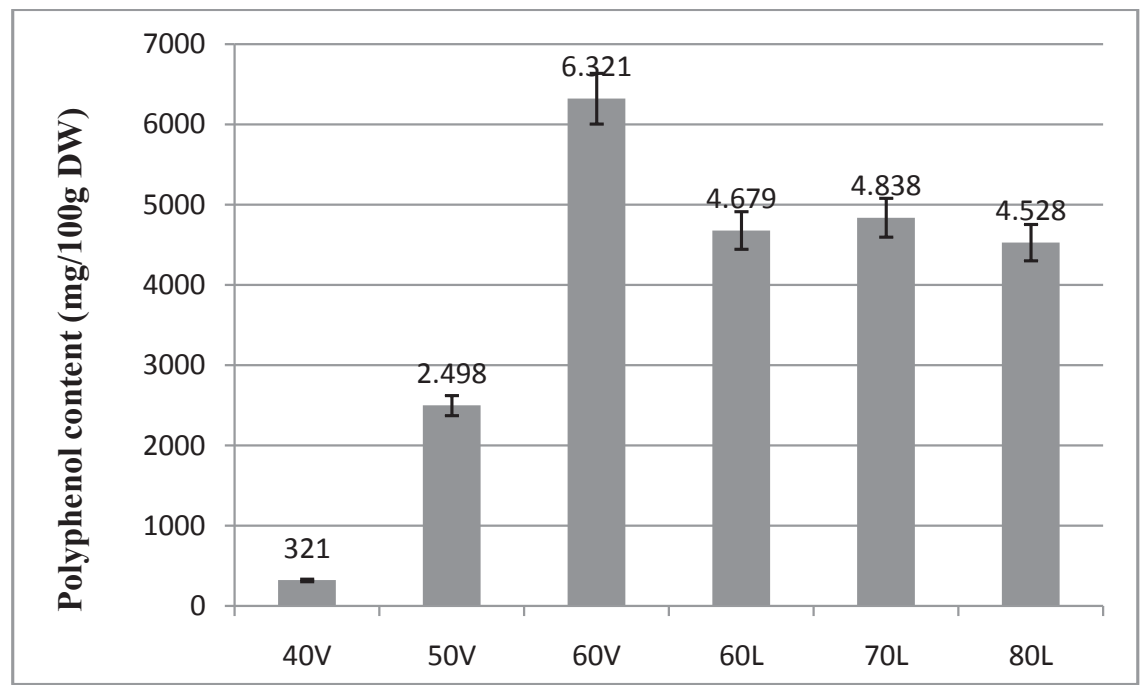

Figure 5: The polyphenol content of the dried samples

Figure 5 shows the polyphenol content of the dried samples. The $60 \mathrm{~V}$ sample shows the highest polyphenol content. Polyphenol contents yield almost the same values in the case of atmospheric drying.

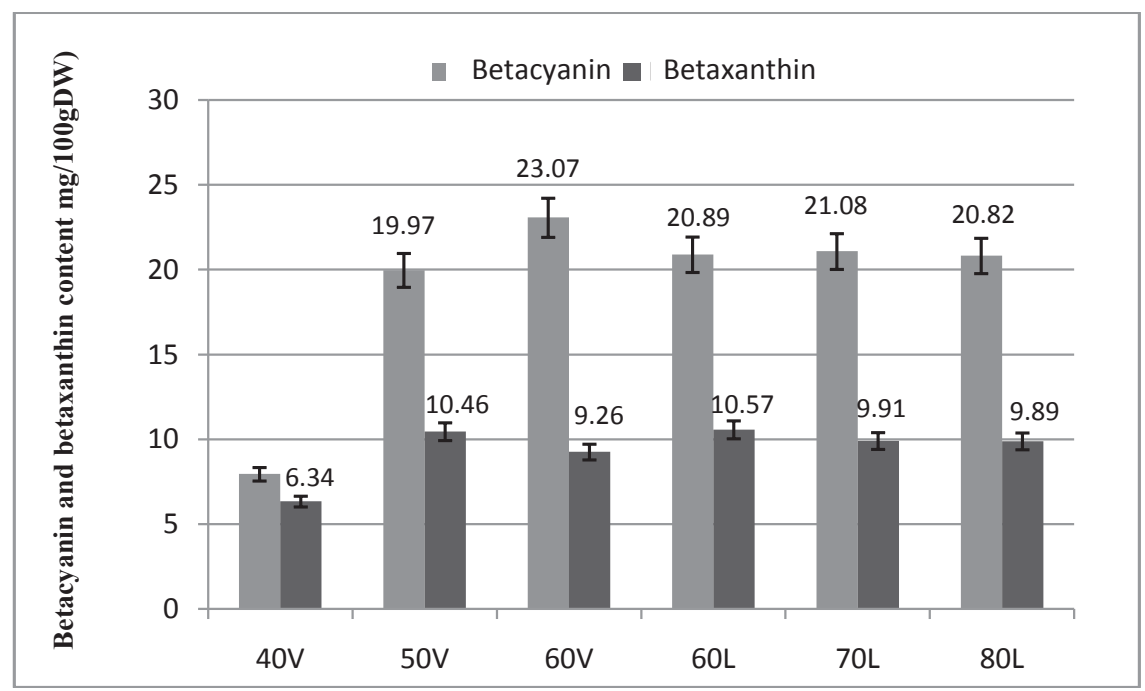

Figure 6: Betacyanin and betaxanthin contents of the dried samples 
Based on Figure 6, there is a substantial difference between the $40 \mathrm{~V}$ and the other samples. Betacyanin values do not show remarkable deviation, except for the $40 \mathrm{~V}$ sample. Betaxanthin content is the highest in the case of the $60 \mathrm{~V}$ sample.

\section{Conclusions}

Based on the measurements, vacuum drying is a more favourable method to preserve the nutritional characteristics, but it is necessary to dry the samples for the same moisture content and water activity because high moisture content and water activity affect the extraction and stability of betalain. In the future, it is worth drying samples with same moisture content and investigating the effects of more drying methods and temperatures.

\section{References}

[1] M. Hájas, Gyökérzöldségek termelése (Production of root vegetables). Mezőgazdasági Kiadó. Budapest. (1976) 87-100.

[2] S. Balázs, Zöldségtermesztők kézikönyve (Handbook of vegetable growers). Mezőgazda Kiadó. Budapest. (2004) 138-150.

[3] M. Takácsné Hájos, A céklatermesztésünk növelésének indokai és lehetőségei (Reasons and possibilities of increasing our beetroot cultivation). Acta Agraria Debreceniensis, 9. (2002) 131-134.

[4] K. Ravichandran, N. M. M. T. Saw, A. A. A. Mohdaly, A. M. M. Gabr, A. Kastell, H. Riedel, Z. Cai, D. Knorr, I. Smetanska, Impact of processing of red beet on betalain content and antioxidant activity. Food Research International, 50. (2013) 670-675.

[5] B. Nemzer, Z. Pietrzkowski, A. Sporna, P. Stalica, W. Thresher, T. Michalowski, S. Wybraniec, Betalainic and nutritional profiles of pigment-enriched red beet root (Beta vulgaris L.) dried extracts. Food Chemistry, 127. (2011) 42-53.

[6] J. Csapó, K. Zs. Csapóné, Élelmiszer-kémia (Food Chemistry). Mezőgazdasági Kiadó, Budapest. (2003) 234.

[7] V. G. Georgiev, J. Weber, E. M. Kneschke, P. N. Denev, T. Bley, A. I. Pavlov, Antioxidant activity and phenolic content of betalain extracts 
from intact plants and hairy root cultures of the red beetroot Beta vulgaris cv. Detroit dark red. Plant Foods Hum. Nutr., 65. (2010) 105111.

[8] V. L. Singleton, J. A. Rossi, Colorimetry of total phenolics with phosphomolybdic phosphotungstic acid "reagents". Am. J. Enol Vitic., 16. (1965) 144-158.

[9] I. I. F. Benzie, J. J. Strain, The ferric reducing ability of plasma (FRAP) as a measuring of "antioxidant power": The FRAP assay. Anual Biochem., 239. (1996) 70-76.

[10] R. Castellar, J. M. Obon, M. Alacid, J. A. Fernández-Lopez, Color properties and stability of betacyanins from Opuntia fruits. J. Agric. Food Chem., 51. (2003) 2771-2776.

[11] F. C. Stinzing, K. M. Herbach, M. R. Mosshammer, R. Carle, W. Yi, S. Sellappan, C. C. Akoh, R. Bunch, P. Felker, Color, betalain pattern, and antioxidant properties of cactus pear (Opuntia spp.) clones. $J$. Agric. Food Chem., 53. (2005) 442-451. 